\title{
Pengaruh Pembelajaran Dengan Pendekatan Open Ended Terhadap Kemampuan Pemecahan Masalah Matematis Mahasiswa Pada Mata Kuliah Kalkulus FKIP UMSU
}

\author{
Feri Haryati ${ }^{1 *}$, Ambar Wulan Sari ${ }^{2}$ \\ Universitas Muhammadiyah Sumatera Utara \\ email: ririmida@yahoo.com
}

\begin{tabular}{|c|c|}
\hline Abstrak & Artikel Info \\
\hline $\begin{array}{l}\text { Penelitian ini bertujuan untuk melihat adanya pengaruh } \\
\text { pendekatan open ended terhadap kemampuan pemecahan } \\
\text { masalah matematis dan soft skill mahasiswa. Metode yang } \\
\text { digunakan dalam penelitian ini adalah quasi eksperimen } \\
\text { menggunakan desain nonequivalent control group design. } \\
\text { Populasi dalam penelitian ini adalah seluruh mahasiswa } \\
\text { semester satu pendidikan matematika UMSU tahun ajaran } \\
\text { 2017/2018, dengan menggunakan dua kelas yang telah } \\
\text { ditentukan. Kelas eksperimen mendapatkan pembelajaran } \\
\text { dengan pendekatan open ended, sedangkan kelas kontrol } \\
\text { menggunakan metode konvensional. Instrumen yang } \\
\text { digunakan berupa tes uraian, angket soft skill, lembar } \\
\text { observasi dan pedoman interview. Kesimpulan diambil } \\
\text { berdasarkan hasil pengolahan dan analasis data } \\
\text { menggunakan uji T-test dengan bantuan program Microsoft } \\
\text { Excel dan program SPSS 17. Hasil yang diperoleh bahwa } \\
\text { kemampuan pemecahan masalah matematis dan soft skill } \\
\text { mahasiswa lebih baik dari kelas konvensional, sehingga } \\
\text { dapat disimpulkan bahwa pendekatan open ended } \\
\text { berpengaruh terhadap kemampuan pemecahan masalah } \\
\text { matematis dan soft skill mahasiswa. }\end{array}$ & $\begin{array}{c}\text { Received: } \\
\text { 10 Februari } 2018 \\
\text { Revised: } \\
\text { 14 Maret 2018 } \\
\text { Accepted: } \\
\text { 21 Mei 2018 }\end{array}$ \\
\hline $\begin{array}{c}\text { Keyword: Pendekatan Open Ended, Kemampuan } \\
\text { Pemecahan Masalah Matematis Mahasiswa, } \\
\text { Soft Skill Mahasiswa }\end{array}$ & \\
\hline
\end{tabular}

\section{A. Pendahuluan}

Peraturan Pemerintah Nomor 32

Tahun 2013 tentang Standar Nasional

Pendidikan menyatakan bahwa pendidik harus memiliki kualifikasi akademik dan kompetensi sebagai agen pembelajaran, sehat jasmani dan rohani, serta memiliki kemampuan untuk mewujudkan tujuan pendidikan nasional. Yang dimaksud pendidik 
sebagai agen pembelajaran (learning agent) adalah peran pendidik antara lain sebagai fasilitator, motivator, pemacu, dan pemberi inspirasi belajar bagi peserta didik.

Committee on Undergraduate Program in Mathematics (CUPM) merekomendasikan bahwa setiap matakuliah dalam matematika hendaknya merupakan aktivitas yang akan membantu mahasiswa dalam pengembangan analisis, penalaran kritis, pemecahan masalah dan keterampilan komunikasi. Oleh karena itu pembelajaran matematika yang diberikan di perguruan tinggi harus dapat mengasah mahasiswa agar mereka memiliki kompetensi dasar dalam matematika, yaitu pemahaman, pemecahan masalah, penalaran, koneksi, dan komunikasi matematis, berpikir kritis, dan berpikir kreatif.

Mahasiswa pendidikan matematika adalah calon calon guru atau pendidik yang perlu menguasai berbagai kompetensi atau kemampuan matematis yang dapat diterapkan didalam kelas. salah satu kemampuan yang harus dimiliki oleh calon guru pendidikan matematika adalah Kemampuan pemecahan masalah matematis yang merupakan hal yang sangat penting dimiliki oleh seorang pendidik atau mahasiswa calon guru matematika, disamping berbagai kemampuan lain, seperti kemampuan penalaran, pembuktian, representasi matematis, dan komunikasi matematis.

Dosen memiliki peran dan tanggung jawab yang sangat besar dalam pencapaian tujuan pembelajaran yang dirumuskan. Pencapaian tujuan pembelajaran dipengaruhi oleh berbagai faktor, salah satu diantaranya adalah metode pembelajaran yang digunakan. Untuk mewujudkan proses pembelajaran yang dapat meningkatkan kemampuan pemecahan masalah matematis mahasiswa maka diperlukan suatu pendekatan pembelajaran yang berpusat pada mahasiswa. Hal ini sejalan menurut Peraturan Menteri tahun 2013 tentang standar nasional pendidikan tinggi menyatakan bahwa proses pembelajaran harus dilaksanakan secara interaktif, menyenangkan, menantang dan memotivasi mahasiswa untuk berpatisipasi aktif, serta memberikan kesempatan untuk berkreativitas dan mandiri. 
Untuk

mengakomodir

permasalahan tersebut, salah satu

pembelajaran yang memungkinkan

digunakan oleh dosen adalah dengan pendekatan open ended yang merupakan pembelajaran yang mengikuti perkembangan ilmu pengetahuan dan teknologi. Melalui pembelajaran dengan pendekatan open ended mahasiswa diberikan ruang untuk mengeksplorasi permasalahan yang ada, mengkomunikasikan idenya, serta dapat menyajikan masalah baru melalui masalah awal, sehingga pembelajaran akan cenderung berpusat pada mahasiswa serta mahasiswa menjadi interaktif, menyenangkan, menantang dan memotivasi mahasiswa untuk berpatisipasi aktif, serta memberikan kesempatan untuk berkreativitas dan mandiri.

\section{B. Kajian Pustaka}

\section{Pendekatan Open Ended}

Shimada, menyatakan bahwa pendekatan open-ended berawal dari pandangan bagaimana mengevaluasi kemampuan siswa secara objektif dalam berfikir tingkat tinggi matematika. Seperti yang telah diketahui bahwa kemampuan tingkat tinggi matematika salah satunya adalah mengenai kemampuan komunikasi. Pendekatan open-ended sendiri muncul di Jepang atas reaksi pembelajaran matematika saat itu yang aktifitas kelasnya disebut "issei jugyow" (frontal teaching), dimana guru menjelaskan konsep baru di depan kelas kepada seluruh siswa, kemudian memberikan contoh untuk penyelesaian beberapa soal.

Pembelajaran dengan pendekatan open-ended menampilkan suatu masalah yang dapat diselesaikan dengan multi jawaban atau metode solusi yang berbeda. Selain itu, jenis masalah yang disajikan bukanlah masalah rutin, melainkan masalah nonrutin yang bersifat terbuka. Dahlan mengklasifikasikan jenis masalah yang ada dalam pembelajaran dengan pendekatan open-ended dalam tiga bentuk, yakni: Process is open, end product are open dan ways to develop are open. Proses terbuka maksudnya adalah jenis soal yang diberikan memiliki banyak cara penyelesaian yang benar. Hasil akhir yang terbuka maksudnya adalah jenis soal yang diberikan memiliki jawaban benar yang 
banyak (multiple), sedangkan cara pengembangan lanjutannya terbuka maksudnya, ketika siswa telah selesai menyelesaikan masalahnya (soal), mereka dapat mengembangkan permasalahan baru dengan mengubah kondisi dari masalah awal.

Pendekatan open-ended dipilih sebagai alternatif pembelajaran apabila dosen mengharapkan mahasiswanya:

1) Aktif berpartisipasi dalam pembelajaran.

2) Merasa puas dengan mampu menuangkan gagasan-gagasan sendiri.

3) Mengalami pengalaman belajar matematika yang menyenangkan.

4) Mencapai tingkat berpikir yang lebih tinggi dari sebelumnya.

Menurut Hancock soal openended merupakan soal yang memiliki lebih dari satu cara penyelesaian yang benar, mempunyai lebih dari satu jawaban benar dan siswa dapat menjawabnya dengan caranya sendiri tanpa harus mengikuti proses pengerjaan yang sudah ada. Nilai dari soal-soal open-ended bukan hanya terletak pada format dan materi yang terkandung dalam soalan, tetapi sangat ditentukan oleh prosedur, suasana, dan cara penyelesaiannya.

Ada dua aspek yang penting dalam penyajian masalah menurut Brown dan Walter yaitu accepting yang berkaitan dengan kemampuan siswa dalam memahami situasi yang sudah ditentukan, dan challege yang berkaitan dengan sejauhmana siswa merasa tertantang untuk situasi yang diberikan sehingga melahirkan kemampuan untuk mengajukan masalah matematika.

Untuk mengkonstruksi soal open-ended yang baik, Pinal mengungkapkan dosen harus memperhatikan hal-hal berikut, yaitu: (1) Soal-soal harus memiliki multi jawaban yang benar atau multi cara penyelesaian; (2) Siswa diberi kesempatan untuk mengungkapkan alasan atas jawaban yang diberikan; (3) Siswa dapat berpikir cara lain; (4) Siswa dapat berpikir refleksi; (5) Menyusun problem serupa; (6) Penalaran adaptif dan menerapkan pada situasi lain; (7) Suasana kelas harus mendukung bagi siswa dalam menyelesaikan soal open-ended baik tempat, lembar kerja maupun media; dan (8) Guru harus memperhatikan 
bagaimana cara kerja siswa dalam mengerjakan soal, baik dalam individu maupun kelompok, kapan perlu memberikan scaffolding untuk kelompok yang lambat.

Dari uraian di atas pembelajaran dengan pendekatan open-ended yang dimaksud dalam penelitian ini adalah pembelajaran dengan penempatan mahasiswa sebagai pusat belajar. Inti dari pembelajaran dengan pendekatan open-ended adalah penyajian masalah kepada mahasiswa. Dalam suatu masalah, mahasiswa diberi kesempatan untuk memperoleh pengetahuan baru melalui eksplorasi, menemukan, mengenali, dan memecahkan masalah dengan berbagai cara. Pada bagian ini mahasiswa diharapkan mampu mengkomunikasi idenya kepada mahasiswa lain baik dengan diskusi kelompok maupun penyajian di depan kelas. Mahasiswa diberi kesempatan untuk berfikir bebas sesuai dengan pengetahuan awalnya. Dengan demikian kemampuan komunikasi matematis mahasiswa akan berkembang dan bukan tidak mungkin terjadi peningkatan.

\section{Pembelajaran Konvensional}

Tidak dapat dipungkiri bahwa pembelajaran yang terjadi baik dilingkungan pendidikan menengah bawah sampai atas lebih pada pembelajaran yang bersifat konvensional. Nasution memberikan gambaran ciri pembelajaran biasa (konvensional) adalah:

1) bahan pelajaran disajikan kepada kelompok, kepada kelas sebagai keseluruhan tanpa memperhatikan siswa secara individual,

2) kegiatan pembelajaran umumnya berbentuk ceramah, kuliah, tugas tertulis, dan media lain menurut pertimbangan guru,

3) mahasiswa umumnya bersifat pasif, karena terutama harus mendengarkan penjelasan guru,

4) dalam kecepatan belajar mahasiswa harus belajar menurut kecepatan umumnya ditentukan oleh kecepatan guru mengajar,

5) keberhasilan belajar umumnya dinilai oleh guru secara subjektif,

6) diharapkan bahwa hanya sebagian kecil saja akan menguasai bahan pelajaran secara tuntas, sebagian 
lagi menguasai sebagian saja dan ada lagi yang akan gagal,

7) dosen terutama berfungsi sebagai penyebar atau penyalur pengetahuan (sebagai sumber informasi atau pengetahuan).

Dari beberapa pendapat di atas, pembelajaran konvensional yang dimaksud dalam penelitian ini adalah pembelajaran yang berpusat pada dosen, mahasiswa sebagai penerima pesan yang bersifat pasif, pemberian contoh dan latihan pada mahasiswa tanpa melibatkan pengetahuan awal akan konsep tersebut sehingga pembelajaran tersebut tidak bermakna bagi mereka.

\section{Metode Penelitian}

\section{Desain Penelitian}

Penelitian ini merupakan penelitian kuasi eksperimen atau eksperimen semu yang terdiri dari dua kelompok. Desain penelitian yang digunakan adalah desain kelompok kontrol non-ekuivalen. ${ }^{1}$ Pada desain ini, subjek tidak dikelompokkan secara

1 Ruseffendi, Dasar-Dasar Penelitian Pendidikan dan Bidang Non Ekasakta Lainnya, (Bandung: Tarsito, 2005), h. 56.

Copyright (C) 2018. Intiqad: Jurnal Agama dan Pendidikan Islam. This is an open acces article under the CC-BY-SA lisence (https://creativecommons.org/licenses/by-sa/4.0/). acak, tetapi peneliti menerima keadaan subjek seadanya. Pada penelitian ini terdapat pretes, perlakuan yang berbeda (treatment), dan postes. Secara singkat, desain penelitian ini adalah sebagai berikut:

Kelas Eksperimen: $\quad \mathrm{O} \quad \mathrm{X} \quad \mathrm{O}$

Kelas Kontrol $\quad: \quad \mathrm{O} \quad \mathrm{O}$

\section{Keterangan:}

O: Pretes atau postes.

$\mathrm{X}$ : Pembelajaran dengan pendekatan open-ended

--: Subjek tidak dikelompokkan secara acak.

\section{Populasi Penelitian}

Populasi dalam penelitian ini adalah seluruh mahasiswa semester pertama Program Studi Pendidikan Matematika Universitas Muhammadiyah Sumatera Utara tahun akademik 2016/2017. Sampel terdiri dari 2 kelas yang dipilih secara acak, selanjutnya ditentukan kelas pertama sebagai kelas eksperimen (pembelajaran menggunakan pendekatan metakognitif) dan kedua sebagai kelas kontrol (pembelajaran konvensional). 


\section{Variabel Penelitian}

Variabel dalam penelitian ini adalah pembelajaran dengan pendekatan open ended sebagai variabel bebas, dan kemampuan pemecahan masalah matematis dan soft skill mahasiswa sebagai variabel terikat
Untuk memperoleh data dalam penelitian ini digunakan beberapa instrumen yang terdiri dari tes uraian kemampuan komunikasi mahasiswa dan angket soft skill serta lembar observasi dan wawancara.

\section{Hasil Penelitian dan Pembahasan}

\section{Instrumen Penelitian}

Tabel 1

Statistik Deskriptif Skor Postes Kemampuan Pemecahan Masalah Matematis

Descriptive Statistics

\begin{tabular}{|l|r|r|r|r|r|}
\hline & $\mathrm{N}$ & Mean & Std. Deviation & Minimum & \multicolumn{1}{c|}{ Maximum } \\
\hline kelas_eks & 33 & 30.4848 & 7.00500 & 20.00 & 60.00 \\
kelas_kontrol & 33 & 15.6061 & 5.80377 & 10.00 & 30.00 \\
\hline
\end{tabular}

Tabel 1 memperlihatkan bahwa

rerata skor kemampuan komunikasi pemecahan masalah matematis mahasiswa kelas kontrol setelah pembelajaran lebih kecil dibandingkan dengan siswa kelas eksperimen, yaitu rerata skor kelas eksperimen 30,48 sedangkan rerata skor kelas kontrol 15.60. Perbedaannya hanya sekitar 14,40. Berdasarkan deviasi dapat dilihat bahwa penyebaran kemampuan pemecahan masalah matematis mahasiswa setelah adanya pembelajaran untuk kelas eksperimen lebih menyebar daripada kelas kontrol. Hal ini dikarenakan deviasi standar kelas eksperimen terlihat lebih besar dibandingkan deviasi standard kelas kontrol.

Selanjutnya dilakukan analisis data postes mahasiswa untuk mengetahui kemampuan pemecahan masalah matematis mahasiswa kelas eksperimen dan siswa kelas kontrol untuk memastikan apakah peningkatan kemampuan pemecahan masalah matematis kedua kelas tersebut berbeda secara signifikan atau tidak. Untuk melihat uji rerata, terlebih dahulu dilakukan uji normalitas dan uji 
homogenitas, dengan derajat signifikansi setiap uji sebesar 0,05 atau tingkat kepercayaan sebesar $95 \%$.

Untuk melihat pemecahan masalah matematis yang dicapai oleh mahasiswa digunakan data postes. Rerata skor postes merupakan gambaran kemempuan pemecahan masalah matematis baik dengan pembelajaran pendekatan open ended maupun dengan pembelajaran konvensional.

Berdasarkan pengolahan terhadap skor postes, diperoleh skor minimum $\left(x_{\min }\right)$, skor maksimum ( $\left.x_{\text {maks }}\right)$, skor rerata (mean), dan deviasi standar (SD) seperti pada Tabel. 1

Untuk mengetahui kebenaran rerata di atas perlu dilakukan perhitungan pengujian statistik dengan menggunakan uji perbedaan rerata dua populasi terhadap hipotesis berikut.

\section{Hipotesis:}

"Kemampuan pemecahan masalah matematis mahasiswa yang memperoleh pembelajaran dengan pendekatan Open ended lebih baik daripada mahasiswa yang memperoleh pembelajaran konvensional".

Sebelum melakukan uji perbedaan rerata, terlebih dahulu 


\section{Tabel 2}

Hasil Uji Normalitas Skor Postes Kemampuan Pemecahan Masalah Matematis Mahasiswa Kelompok Eksperimen dan Kontrol

One-Sample Kolmogorov-Smirnov Test

\begin{tabular}{|ll|r|r|}
\hline & & kelas_eks & kelas_kontrol \\
\hline Normal Parameters ${ }^{\mathrm{a}, \mathrm{b}}$ & & 33 & 33 \\
& Mean & 30.4848 & 15.6061 \\
& Std. Deviation & 7.00500 & 5.80377 \\
Most Extreme Differences & Absolute & .155 & .208 \\
& Positive & .155 & .208 \\
& Negative & -.143 & -.106 \\
& & .890 & 1.196 \\
Kolmogorov-Smirnov Z & & .407 & .114 \\
Asymp. Sig. (2-tailed) & & &
\end{tabular}

a. Test distribution is Normal.

b. Calculated from data.

Dari Tabel 2 diperoleh nilai signifikansi (sig.) masing-masing sebesar 0,407 dan 0,114 untuk data postes kemampuan pemecahan masalah matematis mahasiswa pada kelompok eksperimen dan kelompok kontrol. Pada taraf signifikansi $\alpha=$ 0,05 , nilai signifikansi tersebut lebih besar dari nilai $\alpha=0,05$ sehingga hipotesis nol diterima. Artinya, kedua kelompok data skor data postes kemampuan pemecahan masalah matematis mahasiswa ini berdistribusi normal.

Karena data rerata postes kemampuan pemecahan masalah matematis mahasiswa di kedua kelas tersebut berdistribusi normal, maka perlu dilakukan uji homogenitas. Perhitungan uji homogenitas N-Gain dapat dilihat pada tabel 5.3 berikut:

Tabel 3

Hasil Uji Homogenitas Data Postes Kemampuan Pemecahan Masalah Matematis Mahasiswa Kelas Eksperimen Dan Kontrol

Test of Homogeneity of Variances

data postes

\begin{tabular}{|c|c|c|c|}
\hline Levene Statistic & df1 & df2 & Sig. \\
\hline
\end{tabular}

Copyright (C) 2018. Intiqad: Jurnal Agama dan Pendidikan Islam. This is an open acces article under the CC-BY-SA lisence (https://creativecommons.org/licenses/by-sa/4.0/). 


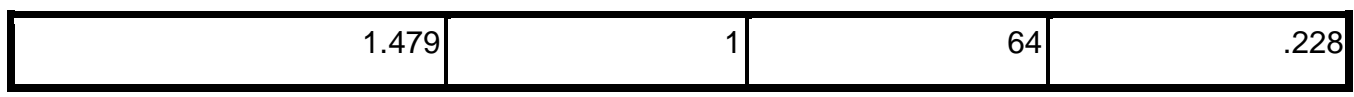

Berdasarkan tabel 5.5 diketahui bahwa nilai signifikansi hitung lebih besar dibandingkan nilai $\alpha=0,05$, sehingga $\mathrm{H}_{0}$ diterima, artinya varians pada kelas eksperimen dan kontrol adalah sama. Karena data berdistribusi normal dan variansnya homogen maka selanjut dilakukan untuk uji perbedaan data postes kemampuan pemecahan masalah matematis mahasiswa di kelas eksperimen dan kontrol menggunakan uji Independendent sample T Test.

Untuk mengetahui signifikansi perbedaan rerata kedua kelompok digunakan rumusan hipotesis uji perbedaan rerata kemampuan pemecahan masalah matematis mahasiswa dengan hipotesis sebagai berikut:

$$
\begin{aligned}
\mathrm{H}_{0} & \text { : Kemampuan pemecahan } \\
& \text { masalah matematis mahasiswa } \\
& \text { yang memperoleh pembelajaran } \\
& \text { dengan pendekatan Open ended } \\
& \text { sama dengan peningkatan } \\
& \text { kemampuan }
\end{aligned}
$$

matematis mahasiswa yang memperoleh pembelajaran konvensional.

$\mathrm{H}_{1}$ : Kemampuan pemecahan masalah matematis mahasiswa yang memperoleh pembelajaran dengan pendekatan Open ended lebih baik daripada mahasiswa yang memperoleh pembelajaran konvensional.

Uji statistik menggunakan SPSS pada kedua kelompok data. Dengan kriteria uji, pada taraf signifikansi $\alpha$ tolak $\mathrm{H}_{0}$ jika $p$-value lebih kecil dari $\alpha$. hasil rangkumannya dapat dilihat pada Tabel 4 berikut: 
Tabel 4

Uji Perbedaan Rataan Kemampuan Pemecahan Masalah Matematis

\begin{tabular}{|r|r|r|r|r|}
\hline \multicolumn{5}{|c|}{ Independent sampel test } \\
\hline \multicolumn{1}{|c|}{$\mathrm{T}$} & \multicolumn{1}{|c|}{$\mathrm{df}$} & Sig. (2-tailed) & Mean Difference & Std. Error Difference \\
\hline 5.365 & 64 & .001 & .0803909 & .0149856 \\
5.365 & 63.762 & .001 & .0803909 & .0149856 \\
\hline
\end{tabular}

Dari Tabel 4 di atas diketahui bahwa nilai signifikansi (sig.) sebesar 0,001 lebih kecil dari nilai $\alpha=0,05$, sehingga dapat disimpulkan bahwa hipotesis nol ditolak. Artinya, Kemampuan pemecahan masalah matematis mahasiswa yang memperoleh pembelajaran dengan pendekatan Open ended lebih baik daripada mahasiswa yang memperoleh pembelajaran konvensional. Sehingga dapat disimpulkam bahwa pembelajaran open ended berpengaruh terhadap kemampuan pemecahan masalah matematis mahasiswa.

\section{E. Kesimpulan dan Saran}

\section{Kesimpulan}

Berdasarkan hasil penelitian dan pembahasan pada $\mathrm{Bab} \mathrm{V}$ mengenai perbedaan kemampuan pemecahan masalah mahasiswa yang mendapat pembelajaran dengan pendekatan open 
pembelajaran yang digunakan di kelas.

2. Perlunya dilakukan penelitian lanjutan untuk melihat pengaruh pendekatan open ended terhadap kemampuan kognitif dan afektif yang berbeda (ditinjau dari kemampuan afektif kelompok tinggi, menengah dan bawah) dengan menggunakan pendekatan open ended.

\section{Daftar Pustaka}

Adjie, N \& Maulana. (2006). Pemecahan Masalah Matematika. Bandung: Universitas Pendidikan Indonesia Press.

Arikunto, S. (2002). Prosedur Penelitian Suatu Pendekatan Praktek. Jakarta: Rieneka Cipta.

Arikunto, S. (2010). Dasar-Dasar Evaluasi Pendidikan Prosedur. Jakarta: Bumi Aksara. (2006). Panduan Pengembangan Silabus Kurikulum Tingkat Satuan Pendidikan (KTSP). Jakarta: CV. Laksana Mandiri.

Balitbang (2011a). Laporan Hasil TIMSS 2007. Kementrian Pendidikan dan Kebudayaan.
Badan Standar Nasional Pendidikan.

Balitbang (2011b). Laporan Hasil PISA 2009. Kementrian Pendidikan dan Kebudayaan.

Bandura, A. (1977). Self-Efficacy: The Exercise of Control. New York: W. H. Freeman \& Company.

Cardelle, M.E. (1995). Effect of Teaching Metacognitive Skills to Student with low Mathematics Ability. Oxford: Pergamon Press.

Dahar, R.W. (1989). Teori-Teori Belajar. Jakarta: Direktorat Jenderal Pendidikan Tinggi Departemen Pendidikan dan Kebudayaan.

Davis (1996). One Very Complete View (Though Only One). New York: W.H. Freeman.

Dindyal, J. (2005). Emphasis on Problem Solving in Mathematics Textbooks from Two Different Movements. Johor Baru, Malaysia: The Mathematics Education into the $21^{\text {ST }}$ Century Project Universiti Teknologi Malaysia, Reform, Revolution and Paradigm Shifts in Mathematics Education, Johor Baru, Malaysia, Nov 25 ${ }^{\text {th }}-$ Dec 1 st 2005

Elfindri.et al. (2011) Soft Skilluntuk Pendidikan. Jakarta: Baduose Media.

Copyright (C 2018. Intiqad: Jurnal Agama dan Pendidikan Islam. This is an open acces article under the CC-BY-SA lisence (https://creativecommons.org/licenses/by-sa/4.0/). 
Fauzi. A. (2011). Peningkatan Kemampuan Koneksi Matematis dan Kemandirian Belajar Siswa dengan Pendekatan Pembelajaran Metakognitif di Sekolah Menengah Pertama. Bandung: Universitas Pendidikan Indonesia

Fisher, K.W. \& Danies. (1980). A Theory of Cognitive Developmen: The Control and Construction of Hieracies of Skill, Psycology Review, 447-531.

Flavell, J. (1976). Metacognitive Aspects of Problem Solving. In L. Resnick, (Ed.), The nature of intelligence (pp. 231-235). Hillsdale, NJ: Erlbaum.

Garafalo, J. \& Lester F. (1985). Metacognition, Cognitive Monitoring and Mathematical Performance. Journal for Research in Mathematics Education.

Gartman, S. \& Melissa, F. (2000). Metacognition and Mathematical Problem Solving: Helping Student to Ask The Right Question. Journal The Mathematics: W.H. Freeman and Company.

Goos, M. (1995). Metacognitive Knowledge, Belief, and Classroom Mathematics. Eighteen Annual Conference of The
Mathematics Education Research Group of Australasia, Darwin, July 7-10 1995.

Hake, R.R. (1999). Analyzing Change/Gain Scores. [Online]. Tersedia:http://www.physics.india na.edu/ sdi/AnalyzingchangeGain.pdf.

Jacob, C. (2000). Belajar Bagaimana untuk Belajar Matematika: Suatu Telaah Strategi Belajar Efektif_Prosiding_Seminar

Nasional Matematika: Peran Matematika Memasuki Millenium III. ISBN: 979-96152-0-8; 443447. Jurusan Matematika FMIPA ITS Surabaya, 2 November 2000.

Jendriadi. (2009). Keefektifan Pembelajaran Membaca melalui Strategi Bertanya (Question Only strategy) bagi Peningkatan Kemampuan Pemahaman Wacana dan Berpikir Kritis Siswa Kelas V Sekolah Dasar. Tesis pada PPs UPI Bandung: Tidak diterbitkan.

Joyce, B. and Weil, M. (2000) Models of Teaching. New Yersey: Prentice Hall Inc.

Kramarski, B. \& Mevarech, Z.R. (1997). Cognitive- Metacognitive Training within a Problem Solving Based Logo Environment.British Journal of Educational Psychology,67, 425-445. 
Kirkley, J (2003). Principle for Teaching Problem Solving. Indiana University : Plato Learning.

Lester, F. K. (1980). Research on Mathematical Problem Solving. (pp. 286 - 323). Reston Virginia: National Council of Teacher of Mathematics.

Lester. et al. (1989). The Role of Metacognition in Mathematical Problem Solving: A Study of Two grade Seven Classes (Final Report to The National Science Foundation, NSF Project No. MDR 85-50346). Blomington: Indiana University, Mathematics Education Development Center.

Mayer, R. E. (1987). Cognitive, metacognitive, and motivational aspects of problem solving. Instructional Science, 26, 49-63.

Meltzer. (2002). The Relationship Between Mathematics Preparation and Conceptual Learning Gains in Physic: a possible "Hidden in Variable" in Diagnostic Pretest Score. Department of Physics and Astronomy, Iowa State University, Ames, Iowa 50011.

Mulbar, U. (2006). Metakognisi Siswa dalam Menyelesaikan Masalah
Matematika. Universitas Negeri Makassar.

Nindiasari, H. (2004). Pembelajaran Metakognitif untuk Meningkatkan Pemahaman dan Koneksi Matematik Siswa SMU Ditinjau dari Perkembangan Kognitif Siswa. Tesis pada PPs UPI Bandung: Tidak diterbitkan.

NCTM. (2000). Principles \& Standard for School Mathematics. Reston, VA: NCTM.

Neff, Thomas J. \& Citrin, M. (1999). Lesson from The Top. New York: Holt Rinehart and Winston.

Newell, A. \& Simon, H. (1972). Human Problem Solving. Englewood Clifts, NJ: Prentice Hall

Polya, George (1973). How to solve it A New Aspect of Mathematical Method (Second edition). New Jersey: Princeton University Press.

Prabawa, H, W. (2009). Peningkatan Kemampuan Penalaran dan Pemecahan Masalah Matematis Siswa SMA melalui Pembelajaran dengan Pendekatan Metakognitif. Tesis pada PPs UPI Bandung: Tidak diterbitkan.

Puskur (2002). Kurikulum dan Hasil Belajar. Kompetensi Dasar Mata 
Pelajaran Matematika Sekolah

Dasar Madrasah Ibtidaiyah.

Jakarta: Balitbang Depdiknas.

Rohendi, D. Sutarno, H. \& Waryuman,

D. (2010). Penerapan Metode

Pembelajaran Team Assisted

Individualization untuk

Meningkatkan Hasil Belajar

Siswa pada Mata Pelajaran

Teknologi Informasi dan

Komunikasi. Jurnal Pendidikan

Teknologi dan Informasi dan

Komunikasi (PTIK), ISSN 1979-

9462. Vol 3 No.1 / Juni 2010

Ruseffendi, H.E.T. (1991).Penilaian

Pendidikan dan Hasil Belajar

Siswa Khususnya dalam

Pengajaran Matematika untuk

Guru dan Calon Guru. Bandung:

Diktat.

Ruseffendi, H.E.T. (1993). Statistik Dasar untuk Penelitian. Bandung: Depertemen Pendidikan dan Kebudayaan Direktorat Jendral Pendidikan Tinggi Proyek Pembinaan Tenaga Kependidikan Pendidikan Tinggi.

Ruseffendi, H.E.T. (2005). DasarDasar Penelitian Pendidikan dan Bidang Non Ekasakta Lainnya. Bandung: Tarsito.

Sanjaya, W. (2008). Strategi Pembelajaran Berorientasi
Standar Proses Pendidikan.

Bandung: Kencana Prenada

Media Group

Suparno, P. (1997). Filsafat

Konstruktivisme dalam

Pendidikan. Yogyakarta:

Kanisius.

Suzana, Y. (2003) Meningkatkan Kemampuan Pemahaman dan Penalaran Matematis

Siswa SMU melalui

Pembelajaran dengan Pendekatan

Metakognitif. Bandung: Tesis

PPS UPI [tidak dipublikasikan]

Wati, Widya. (2010). Strategi Pembelajaran Soft skill dan Multiple Intelegence.Universitas Negeri Padang. [tidak diterbitkan].

Wardhani, dkk. (2010). Pembelajaran Kemampuan Pemecahan Masalah Matematika di SD. Jakarta: Kemdiknas.

Wijaya, T. (2009). Analisis Data Penelitian Menggunakan SPSS. Yogyakarta: Universitas Atmajaya Yogyakarta.

Wikipedia. (2008). Mathematical Problem. United State: ikimedia Foundation, Inc. [online].

Tersedia:http://en.wikipedia.org/wiki/m athematical_problem 